\title{
Determination of the Energetic Value of Corn, Soybean Meal and Micronized Full Fat Soybean for Newly Hatched Chicks ${ }^{1}$
}

Author(s)

Longo $\mathrm{FA}^{2}$

Menten $\mathrm{JFM}^{3}$

Pedroso $A A^{2}$

Figueiredo $\mathrm{AN}^{2}$

Racanicci $\mathrm{AMC}^{2}$

Gaiotto JB2

Sorbara $\mathrm{JOB}^{2}$

Graduate students - Department of Animal Science - ESALQ/USP, Piracicaba, SP.

Professor, Department of Animal Science, ESALQ/USP - Piracicaba, SP. CNPq scholar.

Mail Address

José Fernando Machado Menten

Departamento de Zootecnia, ESALQ - USP

Av. Pádua Dias, 11

13.418-900 - Piracicaba, SP.

E-mail: jfmmente@esalq.usp.br

\section{Keywords}

Chicks, corn, metabolizable energy, micronized full fat soybean, soybean meal.

\section{- Acknowledgement}

The authors thank FAPESP for financial support and scholarship.

Extracted from PhD thesis developed by the first author at ESALQ/USP. Research project sponsored by FAPESP.

\section{ABSTRACT}

There are some evidences described in the literature showing reduced energy metabolizability of ingredients for newly hatched chicks. Hence, a metabolism trial was carried out with the objective of determining the metabolizable energy of corn grain, soybean meal and micronized full fat soybean for newly hatched chicks. The method of total excreta collection was used in an experiment with 192 male chicks from one to seven days, distributed in a completely randomized design with four treatments and four replicates of twelve birds. Excreta were collected from four to seven days of age. The treatments included a reference diet, two test-diets consisting of $60 \%$ of the reference diet and $40 \%$ of the test ingredients: corn grain (CG) and soybean meal $(\mathrm{SM})$, and one test-diet consisting of $80 \%$ of the reference diet and $20 \%$ of micronized full fat soybean (MFFS). The N-corrected apparent metabolizable energy (AMEn) and the metabolizability coefficient of gross energy (MCGE) of the ingredients determined for the chicks were respectively $3,213 \mathrm{kcal} / \mathrm{kg}$ and $81.6 \%$ for $C G ; 2,085 \mathrm{kcal} / \mathrm{kg}$ and $49.7 \%$ for SM and $4,068 \mathrm{kcal} / \mathrm{kg}$ and $74.8 \%$ for MFFS.

\section{INTRODUCTION}

The study of nutrition and metabolism of newly hatched broiler chicks has proven to be an interesting research area, which may allow the expression of the potential growth rate and meat production of birds by optimizing feed management. In the past decades, growth rates of broilers have increased and enabled to reach final bird weight earlier. Therefore, the dietary management of newly hatched chicks represents an important tool to improve broiler production indexes.

However, the immaturity of the digestive system of young chicks reduces its ability to absorb nutrients compared to older birds. According to Vieira \& Moran Jr. (1999), the intestinal tract of birds is not completely able to digest dietary nutrients until two weeks of age.

During the early stages of broiler development, the ability of digesting carbohydrates and fat is decreased compared to other phases. Noy \& Sklan (1995) showed that chicks at four days of age had reduced absorption rates of lipid and carbohydrate (85\%) and protein (80\%) when compared to older birds.

This lower nutrient utilization during early stages seems to result in decreased metabolizable energy (ME) values of the diets. Previous experiments showed that ME values are depressed between four and seven days of age of broilers (Murakami et al., 1992; Sulistyanto et al., 1998). Corless \& Sell (1999) reported that dietary ME values obtained from birds with four, seven and 14 days old were lower than values calculated using the NRC (1994) tables. 
Longo FA, Menten JFM, Pedroso AA, FigueiredoAN, Racanicci AMC,

Gaiotto JB, Sorbara JOB
The metabolizable energy values of corn-soybean based diets obtained for birds in the first, second and third week of age differed in about $200-250 \mathrm{kcal} / \mathrm{kg}$ when different ingredients for birds were evaluated (Mahagna et al., 1988). However, ME values of wheatsoybean diets differed in $500-1,100 \mathrm{kcal} / \mathrm{kg}$. This low metabolizability observed for wheat-soybean diets was due to higher digesta viscosity caused by the non-starch polysaccharide content of the ingredient. Nutrient digestibility is even more impaired when non-starch polysaccharides are associated to an immature enzymatic system.

Furthermore, the presence of oligosaccharides in soybean meal, such as raffinose and stachyose, is partially responsible for the reduction in the energy digestibility that is seen when considering this ingredient for birds (Leeson \& Summers, 2001).

In birds, the ME value of a corn-soybean diet increases with age until 14 days, when it stabilizes. The reason for the observed increase in energy utilization using this type of diet is based on the increased utilization of starch from corn, fat from corn and supplemental fat, protein from corn and soybean and other carbohydrates from dietary components (Batal \& Parsons, 2002). Therefore, even the usual components of broiler diets can have their utilization diminished during the first few days of age.

Dietary ingredients like soy protein concentrate and soy protein isolate are known to be better utilized by chicks when compared to ordinary soybean meal due to the removal of the oligosaccharide content. It is well established that these compounds act as antinutritional factors and reduce protein digestibility in birds (Parsons et al., 2000).

The use of micronized full fat soybean in pre-starter broilers diets is an alternative for the use of soybean meal. This ingredient is produced using selected soybeans that are heated, dehulled, ground and micronized. The process results in a product with small particle size (between 30 and $300 \mu \mathrm{m}$ ) and completely free from hulls, which results in an increase of nutrient utilization by broilers (Goldflus, 2001).

The intake of pre-starter diet is low and corresponds to only $3.5 \%$ of total feed consumption, which justifies the use of high-quality ingredients in feed production (Penz Jr. \& Vieira, 1998). In order that high-quality and expensive ingredients can be used in pre-starter diets, the evaluation of the actual capacity of ingredient utilization is critical for the formulation of efficient diets and for the improvement of nutrient utilization by young birds.
Determination of the Energetic Value of Corn, Soybean Meal and Micronized Full Fat Soybean for Newly Hatched Chicks
However, the use of high-quality and expensive ingredients in the composition of pre-starter diets is extremely dependent on precise evaluation of the utilization capacity of the standard ingredients, such as corn and soybean meal. The knowledge of these values would allow nutritionists to produce efficient diets that improve nutrient utilization by young birds.

The objective of this work was to determine the metabolizable energy value and the metabolizability coefficient of gross energy for corn, soybean meal and micronized full fat soybean for newly hatched broiler chicks.

\section{MATERIAL AND METHODS}

A metabolism assay was conducted in an environmentally controlled room at the Department of Animal Science, ESALQ/USP, Piracicaba/SP, Brazil. One hundred and ninety-two AgRoss male broiler chicks with one day of age were distributed in a completely randomized design with four treatments and four replicates of 12 birds per cage. The birds were raised on battery cages with automatic heating and a tray under the screen floor to collect excreta.

The treatments included a reference diet (Table 1) formulated to meet nutritional requirements of birds in the early stages (Rostagno et al., 2000) and three test diets. Two of the test diets were composed of $60 \%$ of the reference diet and $40 \%$ of the tested ingredient (corn or soybean meal). In the third test diet, $20 \%$ of the reference diet was substituted for micronized full fat soybean meal.

Birds were fed the experimental diets from one to three days of age, corresponding to an adaptation period. Total excreta collection method was then performed for four consecutive days. Feed intake and excreta production were recorded daily. Iron oxide was added to the experimental diets to dye the excreta and establish the start and the end of the collection period.

The produced excreta were collected twice a day, identified and stored in a freezer until analysis. After thawing and homogenization, representative samples of each replicate were dried in an oven at $55^{\circ} \mathrm{C}$ for 72 hours and ground. Samples of dietary ingredients, experimental diets and excreta were analyzed for dry matter, nitrogen, total fat and gross energy. 
Longo FA, Menten JFM, Pedroso AA, FigueiredoAN, Racanicci AMC,
Gaiotto JB, Sorbara JOB

Table 1 - Composition and calculated analysis of the reference diet.

\begin{tabular}{|c|c|}
\hline Ingredients & $\%$ \\
\hline Corn & 57.30 \\
\hline Soybean meal & 36.75 \\
\hline Dicalcium phosphate & 1.89 \\
\hline Limestone & 1.00 \\
\hline Salt & 0.50 \\
\hline DL-Methionine & 0.21 \\
\hline L-Lysine. $\mathrm{HCl}$ & 0.18 \\
\hline Choline-Cl $60 \%$ & 0.05 \\
\hline Vegetable oil & 1.92 \\
\hline Vitamin mix & 0.10 \\
\hline Mineral $\mathrm{mix}^{2}$ & 0.10 \\
\hline \multicolumn{2}{|l|}{ Calculated values } \\
\hline Metabolizable energy, kcal/kg & 2,950 \\
\hline Crude protein, \% & 21.92 \\
\hline Methionine, \% & 0.54 \\
\hline Methionine + Cystine, \% & 0.93 \\
\hline Lysine, \% & 1.31 \\
\hline Available phosphorus, \% & 0.47 \\
\hline Calcium, \% & 0.99 \\
\hline \multicolumn{2}{|c|}{$\begin{array}{l}1 \text { - Levels per } \mathrm{kg} \text { of diet: vitamin } \mathrm{A}, 10,000 \mathrm{IU} \text {; vitamin } \mathrm{D}_{3^{\prime}} 2,000 \mathrm{IU} \text {; } \\
\text { vitamin } \mathrm{E}, 12.5 \mathrm{mg} \text {; vitamin } \mathrm{K}_{3}, 2.5 \mathrm{mg} \text {; thiamin, } 2.4 \mathrm{mg} \text {; riboflavin, } \\
6.0 \mathrm{mg} \text {; pyridoxine, } 3.2 \mathrm{mg} \text {; vitamin } \mathrm{B}_{12}, 0.012 \mathrm{mg} \text {; folic acid, } 1.0 \mathrm{mg} ; \\
\text { pantothenic acid, } 12.5 \mathrm{mg} \text {; niacin, } 30 \mathrm{mg} \text {; selenium, } 0.2 \mathrm{mg} ; \mathrm{BHT}, 15 \\
\mathrm{mg} .2 \text { - Levels per } \mathrm{kg} \text { of diet: manganese, } 65 \mathrm{mg} \text {; copper, } 12 \mathrm{mg} \text {; } \\
\text { zinc, } 50 \mathrm{mg} \text {; iron, } 40 \mathrm{mg} \text {; iodine, } 1 \mathrm{mg} \text {. }\end{array}$} \\
\hline
\end{tabular}

The $\mathrm{N}$-corrected apparent metabolizable energy $\left(A M E_{n}\right)$ was calculated based on data obtained from analysis of experimental diets and excreta, as suggested by Matterson et al. (1965). AME $_{n}$ was calculated for each test ingredient based on energy values obtained for the experimental diets using the following formula:

\section{AMEn ing. = AMEn ref. + (AMEn test - AMEn ref. $)$ (\% replacement /100)}

\section{Where: \\ AMEn: \\ calculated N-corrected apparent metabolizable energy $(\mathrm{kcal} / \mathrm{kg})$; \\ ing.: \\ ref.: \\ test: \\ $\%$ replacement:}

\section{RESULTS AND DISCUSSION}

The values of dry matter (DM), gross energy (GE), crude protein (CP) and total fat (TF) of the studied ingredients (corn, soybean meal and micronized full fat soybean) are presented in Table 2 . The nutrient composition for the test ingredients found in the present study are in agreement with the composition reported in nutritional tables.

The calculated $\mathrm{AME}_{\mathrm{n}}$ and MCGE values for corn, soybean meal and micronized full fat soybean are shown in Table 3, as well as comparative data found in the literature.

Table 2 - Results of dry matter (DM), gross energy (GE), crude protein (CP) and total fat (TF) for corn, soybean meal and micronized full fat soybean*.

\begin{tabular}{|lccc} 
& Corn & Soybean & $\begin{array}{c}\text { Micronized full } \\
\text { fat soybean }\end{array}$ \\
\hline DM (\%) & 89.92 & 91.67 & 98.35 \\
GE (kcal/kg) & 3,943 & 4,197 & 5,438 \\
CP (\%) & 9.26 & 47.52 & 41.70 \\
TF (\%) & 4.63 & 1.80 & 23.12 \\
\hline * As-fed basis. & & & \\
\hline
\end{tabular}

Table 3 - Calculated values and standard deviation of N-corrected apparent metabolizable energy $\left(\mathrm{AME}_{\mathrm{n}}\right.$ ) and metabolizability coefficient of gross energy (MCGE) for corn, soybean meal and micronized full fat soybean.

\begin{tabular}{|c|c|c|c|}
\hline Ingredients & $\begin{array}{c}\text { Calculated AMEn } \\
(\text { (kcal/kg })\end{array}$ & $\begin{array}{c}\text { MCGE } \\
(\%)\end{array}$ & $\begin{array}{c}\text { Literature AMEn } \\
\left(\mathrm{kcal} / \mathrm{kg}^{\mathbf{1}}\right)\end{array}$ \\
\hline Corn & $3,213 \pm 31$ & $81.60 \pm 0.78^{a}$ & 3,360 \\
\hline Soybean meal & $2,085 \pm 45$ & $49.67 \pm 1.07 c$ & 2,385 \\
\hline $\begin{array}{l}\text { Micronized full } \\
\text { fat soybean }\end{array}$ & $4,068 \pm 78$ & $74.81 \pm 1.38^{b}$ & 3,950 \\
\hline
\end{tabular}

$A M E_{n}$ values in the present study for young chicks were 150 and $300 \mathrm{kcal} / \mathrm{kg}$ lower than average values indicated in the literature for corn $(3,360 \mathrm{kcal} / \mathrm{kg})$ and for soybean meal $(2,385 \mathrm{kcal} / \mathrm{kg})$, respectively (NRC, 1994; Rostagno et al., 2000). However, micronized full fat soybean $A M E_{n}$ was similar with values previously reported in the literature $(4,068$ and $3,950 \mathrm{kcal} / \mathrm{kg})$. It should be noted that the reference values for $A M E_{n}$ found in literature for those ingredients were determined using older birds. 
Sulistyanto et al. (1998) analyzed metabolizability of corn and wheat in broiler chicks aged one, three and 10 days and found that the energy values of these ingredients increased with age, although no significant differences were seen.

The results of $A M E_{n}$ reported by Café et al. (1993) for micronized full fat soybean using broiler chicks from 13 to 23 days-old are only $108 \mathrm{kcal} / \mathrm{kg}$ higher $(4,176$ $\mathrm{kcal} / \mathrm{kg})$ than the value determined in this study $(4,068$ $\mathrm{kcal} / \mathrm{kg}$ ).

The MCGE values obtained in the present study for the three ingredients were statistically different $(p<0.01)$. Corn was considered the most efficient ingredient on energy utilization followed by micronized full fat soybean and the least efficient was soybean meal. In agreement with Sulistyanto et al. (1999), corn also demonstrated better energy utilization for young birds compared to other carbohydrate sources like wheat and sorghum.

The calculated values of MCGE obtained from the nutritional data for older birds found in the Brazilian tables (Rostagno et al., 2000) were compared to those determined in this study using young chicks. It was noted that the ability of the younger birds to metabolize energy was similar for micronized full fat soybean (75.3\% vs. $74.81 \%)$, lower for corn (85.7\% vs. 81.6\%) and even lower for soybean meal (60.7\% vs. $49.7 \%)$.

The depressed values of $\mathrm{AME}_{n}$ and MCGE found in this study for corn and soybean meal are probably related to the intrinsic characteristics of the feed ingredients and to the reduced digestion and absorption ability of young birds due to their immature digestive system. This demonstrates that metabolic aspects of young broiler chicks can regulate energy utilization of dietary ingredients.

Nevertheless, similar values observed for $\mathrm{AME}_{n}$ and MCGE for micronized full fat soybean emphasize the importance of an effective quality control and normalization of micronized full fat soybean production, including the complete removal of hulls to insure the efficient utilization of the ingredients by young chicks.

Pupa (2000) did not observe significant differences between MCGE for micronized full fat soybean when fed to swine at 22 days (76.7\%) or at 33 days of age $(80.0 \%)$

The results reported in the present study confirm previous results described by Mahagna et al. (1988). Those authors associated the degree of energy metabolizability of soybean meal measured for young broilers with the increase of viscosity caused by this ingredient on the intestinal digesta. This fact can further reduce the ingredient digestibility when associated to an immature enzymatic system.

An accurate determination of $\mathrm{AME}_{n}$ of corn and soybean meal for newly hatched broiler chicks corroborate the study of alternative ingredients with focus on appropriate and precise diet formulation. On the other hand, the results showed herein and in previous reports (Nir, 1998) suggest that $\mathrm{AME}_{n}$ of feed ingredients described in the literature are overestimated for newly hatched chicks.

The reference diet produced for this experiment was formulated to achieve $2,950 \mathrm{kcal} / \mathrm{kg}$ but the diet actually offered $2,800 \mathrm{kcal} / \mathrm{kg}$, based on the determined AMEn for corn and soybean meal. Therefore, when diets are formulated using alternative ingredients and energy contents that were calculated based on experiments with newly hatched chicks, it must be considered that the reference diet may not contain the expected energetic concentration.

\section{CONCLUSIONS}

$\mathrm{N}$-corrected apparent metabolizable energy values (as-fed) and metabolizability coefficient were 3,213 $\mathrm{kcal} / \mathrm{kg}$ and $81.6 \% ; 2,085 \mathrm{kcal} / \mathrm{kg}$ and $49.7 \%$, and $4,068 \mathrm{kcal} / \mathrm{kg}$ and $74.8 \%$ for corn, soybean meal and micronized full fat soybean, respectively.

The differences between calculated values obtained in this study and literature data indicate a deficiency on digestive and absorptive processes of birds from one to seven days of age and emphasize the importance of the study of ingredients for this phase with the objective of optimizing diet formulation.

\section{REFERENCES}

Batal $A B$, Parsons CM. Effects of age on nutrient digestibility in chicks fed different diets. Poultry Science 2002; 81:400-407.

Café MB, Sakomura NK, Pauwelyn P, Cubas C, Kuana S. Determinação da disponibilidade biológica dos aminoácidos e da energia metabolizável da soja integral processada para aves. In: Conferência APINCO de Ciência e Tecnologia Avícolas; 1993; Campinas, São Paulo, Brasil. p.13.

Corless AB, Sell JL. The effects of delayed access to feed and water on the physical and functional development of the digestive system of young turkeys. Poultry Science 1999; 78:1158-1169.

Goldflus F. Ingredientes derivados do processamento da soja aplicados na nutrição animal. In: Simpósio sobre Manejo e Nutrição de Aves e Suínos e Tecnologia da Produção de Rações; 2001; Campinas, São Paulo. Brasil. p. 97-188. 
Leeson S, Summers JD. Scott's nutrition of the chicken. 4 ed. Guelph (Ontario): University Books; 2001.

Mahagna M, Said N, Nir I, Nitsan Z. Development of digestibility of some nutrients and of energy utilization in young broiler chickens. In: $18^{\circ}$ World's Poultry Congress; 1998; Nagoya, Aichi. Japan. p. 250-251.

Matterson LD, Potter LM, Stutz NW, Singsen EP. The metabolizable energy of feed ingredients for chickens. Research Report 1965; 7:3-11.

Murakami H, Akiba Y, Horiguchi M. Growth and utilization of nutrients in newly hatched chick with or without removal of residual yolk. Growth, Development and Aging 1992; 56:75-84.

Nir I. Mecanismos de digestão e absorção de nutrientes durante a primeira semana. In: Conferência APINCO'98 de Ciência de Tecnologia Avícola; 1998; Campinas, São Paulo, Brasil. p. 81-91.

Noy Y, Sklan D. Digestion and absorption in the young chick. Poultry Science 1995, 74: 366-373.

NRC. National Research Council. Nutrients requirements of poultry, Washington, DC: National Academic Press; 1994. p.155

Parsons CM, Zhang Y, Araba M. Nutritional evaluation of soybean meals varying in oligosaccharide content. Poultry Science 2000, 79:1127-1131.

Penz Jr. AM, Vieira SL. Nutrição na primeira semana. In: Conferência APINCO'98 de Ciência e Tecnologia Avícola; Simpósio Internacional sobre Manejo de Pintos de Corte na Primeira Semana; 1998; Campinas, São Paulo. Brasil. p. 121-139.

Pupa JMR. Avaliação de alimentos e desenvolvimento de dietas líquidas para leitões nas fases pré e pós desmame. [Tese]. Viçosa (MG): Universidade Federal de Viçosa; 2000.

Rostagno HS, Albino LFT, Donzele JL, Gomes PC, Ferreira AS, Oliveira RF, Lopes DC. Tabelas brasileiras para aves e suínos: Composição de alimentos e exigências nutricionais. Viçosa (MG): Universidade Federal de Viçosa; 2000.

SAS Institute. SAS user's guide. version 6.11. Cary (NC); 1996.

Sulistyanto B, Akiba Y, Sato K. Energy utilization of carbohydrate, fat and protein sources in newly hatched chicks. British Poultry Science 1999; 40:653-659.

Sulistyanto B, Akiba Y, Takahashi K, Sato K, Ohtsu H, Konashi S, Kunizane $\mathrm{H}$, Ogura N. Characteristics in energy metabolism of dietary carbohydrate, fat and protein sources in newly hatched chicks. In: $6^{\circ}$ Proceedings Asian Pacific Poultry Congress; 1998; Nagoya, Aichi. Japan. p. 394-395.

Vieira SL, Moran Jr. ET. Effects of egg of origin and chick post-hatch nutrition on broiler live performance and meat yields. World's Poultry Science Journal 1999; 55:125-142. 